strong association between being a bully or being bullied, depression, and severe suicidal ideation highlights the importance of further investigations into the social, psychological, and environmental factors associated with bullying.

\section{Conclusion}

Teachers and clinicians should recognise that being bullied or being a bully are signs of an increased risk of depression and suicidal behaviour among adolescents. Adolescents should be asked if they are involved in bullying either as a victim or as a bully. Whether an intervention is needed to treat depression should be assessed among both bullies and those who are being bullied. A cross disciplinary approach is needed to identify effective interventions to prevent bullying and depression and to reduce the risk of suicide while keeping in mind the close association between these phenomena.

Contributors: RK-H developed and coordinated the formulation of the primary study hypothesis, discussed the core ideas, and participated in planning the collection of data, analysing the data, and writing the paper. MR initiated the school health promotion study and the inclusion of mental health questions in the survey, he discussed the core ideas, and participated in analysing the data and writing the paper. MM brought to the discussion about the core ideas of the study his expertise as a researcher on adolescent suicide and depression, and participated in designing the study, analysing the data, and writing the paper. AR discussed the core ideas of the school health promotion study as well as of this present report, and brought to the process her expertise as an epidemiologist; she also helped analyse the data and write the paper. PR discussed the core ideas of the study and supported the formulation of the hypothesis from the point of view of a clinical adolescent psychiatrist, and participated in writing the paper. MR will act as guarantor for the paper

Funding: None.

Competing interests: None declared.

1 Perry GD, Kusel SJ, Perry CL. Victims of peer aggression. Dev Psychol 1988;24:807-14.

2 Boulton MJ, Underwood K. Bully/victim problems among middle school children. Br J Educ Psychol 1992;62:73-87.

3 Whitney I, Smith PK. A survey of the nature and extent of bullying in junior/middle and secondary schools. Educ Res 1993;35:3-25.
4 Rigby K, Slee PT. Dimensions of interpersonal relations among Australian children and implications for psychological well-being. J Soc Psycho 1992;133:33-42.

5 Rutter M, Taylor E, Hersov M, eds. Child and adolescent psychiatry: modern approaches. 3rd ed. Oxford: Blackwell Science, 1994.

6 Salmon G, James A, Smith DM. Bullying in schools: self reported anxiety, depression and self esteem in secondary school children. BMJ 1998;317:924-5.

7 Williams K, Chambers M, Logan S, Robinson D. Association of common health symptoms with bullying in primary school children. BMJ 1996;313:17-9.

8 Kumpulainen K, Räsänen E, Henttonen I, Almqvist F, Kresanov K, Linna S-L, et al. Bullying and psychiatric symptoms among elementary schoolage children. Child Abuse Negl (in press).

9 Boulton MJ, Smith PK. Bully/victim problems in middle-school children: stability, self-perceived competence, peer perceptions and peer acceptance. Br J Dev Psychol 1994;12:315-29.

10 Byrne BJ. Bullies and victims in a school setting with reference to some Dublin schools. Irish J Psychol 1994;15:574-86.

11 Slee PT. Bullying: health concerns of Australian secondary schoo students. Int J Adolescence Youth 1995;5:215-24.

12 King A, Wold B, Tudor-Smith C, Harel Y. The health of youth: a cross-national survey. Copenhagen, Denmark: WHO Regional Publications, 1996. (European series No 69.)

13 Beck AT, Beck RW. Screening depressed patients in family practice: a rapid technic. Postgrad Med 1972;52:81-5

14 Beck AT, Rial WY, Rickels K. Short form of depression inventory: crossvalidation. Psychol Rep 1974;34:1184-6.

15 Raitasalo R. Elämänhallinta sosiaalipolitiikan tavoitteena. Kansaneläkelaitos, Sosiaali-ja terveysturvan tutkimuksia 1. Helsinki: Kelan omatarvepaino; 1995.

16 Bennett DS, Ambrosini PJ, Bianchi M, Barnett D, Metz C, Rabinovich H Relationship of Beck depression inventory factors to depression among adolescents. J Affect Disord 1997;45:127-34.

17 Kaltiala-Heino R, Rimpelä M, Rantanen P, Laippala P. Finnish modification of the 13-item Beck depression inventory (R-BDI) in screening an adolescent population for depressiveness and positive mood. Nord J Psychiatry (in press)

18 Charman T. The stability of depressed mood in young adolescents: school-based survey. J Affect Disord 1994;30:109-16.

19 Reinherz HZ, Giaconia RM, Silverman AB, Friedman A, Pakiz B, Fros AK et al. Early psychosocial risks for adolescent suicidal ideation and attempts. J Am Acad Child Adolesc Psychiatry 1995;34:599-611.

20 Bowers L, Smith PK, Binney V. Perceived family relationships of bullies, victims and bully/victims in middle childhood. J Soc Personal Relationship. 1994;11:215-32.

21 Slee PT, Rigby K. Australian school children's self appraisal of interpersonal relations: the bullying experience. Child Psychiatry Hum Dev 1993:23:273-82.

22 Rutter M, ed. Psychosocial disturbances in young people: challenges for prevention. New York: Cambridge University Press, 1995.

23 Salmivalli C. Not only bullies and victims. Participation in harassment in schoo classes: some social and personality factors. Turku, Finland: Annales Universitatis Turkuensis, 1998.

(Accepted 10 June 1999)

\title{
Ethnic and sex differences in selection for admission to Nottingham University Medical School
}

\author{
David James, Lisa Driver
}

McManus's study of applications to medical school by students in the United Kingdom and the rest of the European Union ${ }^{1}$ refuelled the debate about discrimination. ${ }^{23}$ McManus showed that 18 measures were independently associated with receiving an offer. ${ }^{1}$ Applicants disadvantaged in selection included those from ethnic minority groups and men. ${ }^{1}$

We analysed applications to Nottingham Medical School by students from the United Kingdom and the rest of the European Union for 1997, looking at sex and ethnic group.

\section{Methods and results}

The admissions process for applicants to University of Nottingham Medical School is detailed in the school's admissions policy document, which is reviewed annually.
Copies are available to all applicants on request and obtainable from us. The process comprises four stages.

Academic stage examines whether the applicant meets the medical school's minimum academic requirement.

Questionnaire stage-Those passing the academic stage complete a questionnaire about work experience, extracurricular activities, and positions of responsibility. These responses are scored.

Statement review-The two statements (applicant's and referee's) on the application form of the applicants with the top 960 questionnaire scores are reviewed by two assessors. Insight, motivation, personality, and communication skills are scored. The 480 candidates with the top scores are selected for interview.

Interview-In an interview of 15 minutes knowledge of Nottingham and the course, insight, motivation, per-
Faculty of Medicine, Queen's Medical Centre, Nottingham NG7 2UH

David James, admissions subdean Lisa Driver, research associate

Correspondence to: Professor James david.james@ nottingham.ac.uk

BMJ 1999;319:351-2 
Decision by ethnic group and sex. Values are numbers of applicants (percentages of group; percentages of each decision category)

\begin{tabular}{|c|c|c|c|c|c|c|c|c|}
\hline \multirow[b]{2}{*}{ Decision category } & \multicolumn{4}{|c|}{ Ethnic group } & \multicolumn{4}{|c|}{ Sex } \\
\hline & White & Non-white* & Total & $\begin{array}{l}P \text { value of } \\
\text { white } v \\
\text { non-white }\end{array}$ & Male & Female & Total & $\begin{array}{l}P \text { value of } \\
\text { male } v \\
\text { female }\end{array}$ \\
\hline Total No of applicants & $1954(76.8)$ & $591(23.2)$ & $2545 \dagger$ & & $1279(47.3)$ & $1422(52.7)$ & 2701 & \\
\hline \multicolumn{9}{|l|}{ Rejection at: } \\
\hline Academic stage & $384(69.4 ; 19.6)$ & 169 (30.6; 28.6) & $553(21.7)$ & $<0.0001$ & $230(57.4 ; 18.0)$ & $171(42.6 ; 13.0)$ & $401(14.8)$ & $<0.0001$ \\
\hline Questionnaire stage & $1015(74.6 ; 51.9)$ & $345(25.4 ; 58.4)$ & 1360 (53.4) & $<0.01$ & $848(49.3 ; 66.3)$ & $871(50.7 ; 61.3)$ & 1719 (63.7) & $<0.0001$ \\
\hline Statement review & $189(87.9 ; 9.7)$ & $26(12.1 ; 4.4)$ & $215(8.5)$ & $<0.0005$ & $74(38.1 ; 5.8)$ & $120(61.9 ; 8.4)$ & $194(7.2)$ & $<0.005$ \\
\hline Interview & $165(88.2 ; 8.4)$ & $22(11.8 ; 3.7)$ & $187(7.4)$ & $<0.0005$ & $47(32.4 ; 3.7)$ & $98(67.6 ; 6.9)$ & $145(5.4)$ & $<0.005$ \\
\hline Offered a place & $201(87.4 ; 10.3)$ & $29(12.6 ; 4.9)$ & $230(9.0)$ & $<0.0005$ & $80(33.0 ; 6.3)$ & $162(67.0 ; 11.4)$ & $242(9.0)$ & $<0.0005$ \\
\hline
\end{tabular}

*Asian (Bangledeshi, Chinese, Indian, Pakistani, other Asian) and black (African, Caribbean, other black)

†Does not include 157 candidates whose ethnic group was not supplied to Universities and Colleges Admission Service.

sonality, communication skills, and interest in medical topics are assessed and scored. Offers are made to the 260 interviewees with the top scores.

In 1997, 2701 candidates from the United Kingdom and the rest of the European Union applied to Nottingham through the Universities Colleges and Admission Service. The decision for each applicant was noted along with ethnic group, sex, and stage of the process. Statistical comparison of frequencies was by $\chi^{2}$ test with Yates's correction.

Significantly more non-white and male applicants were rejected at the academic and questionnaire stages, whereas significantly more white and female applicants were rejected at the statement review and interview stages (table). The net effect was that significantly more white and female applicants were offered a place.

\section{Comment}

Discrimination is "the unfair treatment of a person based on an irrational preference."” Selection by ethnic group or sex would be discriminatory because neither predicts success in a medical course or career. We believe, however, that the higher rates of offers to female and white applicants do not represent discrimination. They arise at the academic and questionnaire stages, which are objectively scored without reference to ethnic group or sex. Indeed, at the statement review and interview, where true discrimination could operate, non-white and male applicants are significantly more likely to be offered a place.

Selection on the basis of academic ability is reasonable: a proved relation exists between this and success on a medical undergraduate course. ${ }^{4}$ Our unpublished data for the first 21 years of Nottingham Medical
School show that scores at O level or GCSE and A level are significant independent predictors of success at all stages of the course. Unlike in McManus's study, for most applicants we can select only on achieved GCSE and predicted $\mathrm{A}$ level grades rather than achieved A level grades.

Nottingham Medical School is the only one to use a questionnaire in selection. It aims at avoiding discrimination by consistently scoring, for all academically suitable applicants, non-academic factors considered relevant to a career in medicine. We now question, however, whether such factors accurately reflect suitability for medicine. Our goal is that selection is only on the basis of evidence based predictors of success, including perhaps psychometric testing. ${ }^{5}$

We encourage all medical schools in the United Kingdom to examine their admission practices as we have done to ensure that the process is fair and non-discriminatory.

Contributors: DJ initiated the research and participated in collecting and analysing the data and in writing the paper. $\mathrm{LD}$ participated in data collection and analysis and writing the paper. DJ is guarantor for the study.

Funding: No additional funding.

Competing interests: None declared.

1 McManus IC. Factors affecting likelihood of applicants being offered a place in medical schools in the United Kingdom in 1996 and 1997: prospective study. BMJ 1998;317:1111-7.

2 Collier J, Burke A. Racial and sexual discrimination in the selection of students for London medical schools. Med Educ 1986;20:86-90.

3 McManus IC, Richards P, Winder BC, Sproston KA, Styles V. Medical school applications from ethnic minority groups: identifying if and when they are disadvantaged. BMJ 1995;310: 496-500.

4 McManus IC, Richards P. Prospective survey of performance of medical students during preclinical years. BMJ 1986;293:124-7.

5 Powis D. How to do it: select medical students. BMJ 1998;317:1149-51.

(Accepted 11 March 1999)
Correspondence to: Dr Vernazza

Pietro.Vernazza@

kssg.ch

continued over

BMJ 1999;319:352-3

\title{
Comparative efficacy of three mumps vaccines during disease outbreak in eastern Switzerland: cohort study
}

\author{
Matthias Schlegel, Joseph J Osterwalder, Renato L Galeazzi, Pietro L Vernazza
}

After the introduction of immunisation against measles, mumps, and rubella, numerous outbreaks of mumps were reported in the $1980 \mathrm{~s}$ and '90s in Switzerland and southern Europe. ${ }^{12}$ The Rubini strain is still widely used in Europe, ${ }^{3}$ and we report here a large outbreak of mumps in a population with a high vaccination rate and examine the differential efficacy of the three vaccine strains. 